\title{
CONCENTRATION OF BIOACTIVE AND MINERAL COMPOUNDS IN ENTERAL TUBE FEED PRODUCTS MADE OF PLANT-BASED INGREDIENTS
}

\author{
Liene Ozola\# ${ }^{\#}$ and Solvita Kampuse \\ Faculty of Food Technology, Latvia University of Life Sciences and Technologies, Jelgava, 22 Rīgas Str., LV-3004, LATVIA \\ \# Corresponding author, lieneozola@inbox.Iv
}

Communicated by Sandra Muižniece-Brasava

\begin{abstract}
Nowadays available products for enteral nutrition are supplemented with synthetic ingredients. The effectiveness of these products is undeniable in the medical industry, but there is concern about bioavailability of synthetic vitamin and mineral compounds in comparison to naturally occurring ones. The aim of this study was to create plant-based formulations for enteral tube feed and to determine their bioactive compound and mineral compound concentration in comparison with the values recommended by the European regulations for special medical purpose food that is not meant to satisfy the nutritional requirements of infants. For this study, five enteral tube feed formulas were made from fruit, berry, and vegetable semi-finished products with added whey protein isolate, canola oil, cod liver oil, iodised salt, and ascorbic acid. The samples were thermally processed and concentration of vitamin $C$, total carotenes, total phenols and mineral compounds: $P, K, \mathrm{Na}, \mathrm{Ca}, \mathrm{Mg}, \mathrm{Fe}, \mathrm{Mn}, \mathrm{Zn}, \mathrm{Cu}$ and Se was determined. All samples showed $<20 \mathrm{mg} \cdot \mathrm{kg}^{-1} \mathrm{per}$ sample of Se, and also concentration of $\mathrm{Zn}$ was under the (EU) 2016/128 requirements. How-

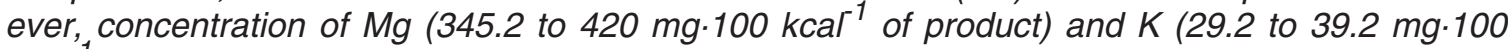
$\mathrm{kcal}^{-1}$ of product) exceeded the maximum levels. Also, the concentration of vitamin $C$ exceeded the maximum, by average two times per sample, as L-ascorbic acid was added in response to previous experiments showing unsatisfying levels.
\end{abstract}

Keywords: special medical purpose food, cook-vide, liquid tube feed.

\section{INTRODUCTION}

Nutrition plays a very important role on an everyday basis to ensure normal body function. However, when dealing with acute and chronic diseases in most organ systems, nutrition-related conditions can occur due to changes in food intake and metabolism with increased catabolism. These conditions are later associated with increased morbidity and death (Cederholm et al., 2017). In cases when dealing with trauma, disease, rehabilitation, elderly care, and nutritional prevention of disease (Cederholm et al., 2017), the assistance of nutritional oral intake of food and liquids is an integral aspect of appropriate medical and nursing care (Druml et al., 2016). Nutritional therapy includes oral, enteral, and parenteral ways of artificial feeding. Enteral feeding is a way of supplying oral food and liquids using nasogastric, gastrostomy or jejunostomy feeding, which is often referred to as enteral tube feeding (Druml et al., 2016; Ozola and Kampuse, 2017).
According to the European Society for Clinical Nutrition and Metabolism (ESPEN) guidelines on ethical aspects of artificial nutrition and hydration, enteral nutrition through a tube, bypassing the action of swallowing can be applied if the patient is unable to take in food orally and also liquid diets in the form of oral nutritional supplements are insufficient (Druml et al., 2016). However, enteral tube feeding is only applicable with a working digestible system and intestinal track, where food can be digested and nutrients assimilated in the body (Weimann et al., 2006; Druml et al., 2016; Ozola and Kampuse, 2017). This method is also preferred to parenteral rout, which allows nutrient and fluid delivery via the intravenous route, and therefore it does not support intestinal functions to the best of their abilities (Druml et al., 2016).

The composition of commercially available nutritional formulas differs depending on the intended use (Ozola and Kampuse, 2017). Most formulas are water-based with a 
source of protein and added additives to ensure needed caloric requirements as well as macro and micro nutrients (See Information on tube feeding, and formula options...). Yeh et al. (2019) also points out that this type of nutrition generally contains less fibre and is high in content of sugar and emulsifiers, which in tests with animal models has shown worsening of colitis. In addition, changes in gut microbiology have been observed, especially when dealing with chronic diseases. A loss of protective anaerobes and the growth of pathogens have been noticed (Yeh et al., 2019).

Fruit and vegetable consumption can have a beneficial effect on human health, attributed to dietary intake of some bioactive compounds like tocopherols, carotenoids, polyphenols, total phenols, and anthocyanins, as well as vitamins, minerals, and fibres (Campaniello, 2017).

Plant materials are considered vital sources of micronutrients. Micronutrients include vitamins and mineral compounds, because small amounts of them are needed for the body (Gharibzahedi and Jafari, 2017; Ozola and Kampuse, 2019). However, there is also a concern over homemade blended diets that tend to be nutritionally unbalanced, can have an increased risk for food contamination, and may compromise enteral access devices. Even when prepared in hospital environments, the use of common foodstuffs have shown unpredictable and inconsistent micronutrient levels, despite using standardised recipes (Vieira et al., 2018). It has to be taken into consideration that different external environment factors like soil, geographical conditions as well as cultivation, fertilisation, weather, and processing and storage conditions can affect the overall composition on fruits and vegetables (Feldmane et al., 2015; Karlsons et al., 2018).

Water-soluble vitamins (B group vitamins and ascorbic acid) are responsible for regulating energy metabolism by modulating the synthesis and degradation of carbohydrate, fat, protein, bioactive compounds. Ascorbic acid (vitamin C) works as an antioxidant. Fat-soluble vitamins (A, D, E, $\mathrm{K}$ ) are stored in human body tissues, but have no direct role in energy metabolism. B-carotene is a precursor of vitamin A. Vitamin E acts as an antioxidant by reducing muscle damage. Vitamin D promotes $\mathrm{Ca}$ absorption and use in bone formation, and vitamin $\mathrm{K}$ functions in coagulation and bone formation (Lukaski, 2004).

At present, one of the leading companies in production of special dietary foods is Nestlé and they also offer blenderised formulas with real food ingredients such as chicken, vegetables and fruit, along with added vitamins, minerals, fibre, and other nutrients (Information on tube feeding, and formula options...). The aim of this study was to create plant-based formulations for enteral tube feed and to determine their bioactive and mineral compound concentration in comparison with the values recommended by the European regulations for special medical purpose food that is not meant to satisfy the nutritional requirements of infants.

\section{MATERIALS AND METHODS}

Sample preparation. For this study, five enteral tube feed products (Z1 to Z5) were made based on their theoretical energy value, calculated using database information on fruit, vegetable, and berry energetic and nutritional values. The basic composition of these samples (see Table 1) included Latvia grown and industrially produced organic fruit, vegetable, and berry semi-finished juices and pulp juices, and in addition, whey protein isolate, rapeseed oil, cod liver oil, iodine salt, and ascorbic acid were added to supplement the nutritional composition and raise the energy value of the product. As given in Commission Delegated Regulation (EU) 2016/128 requirements, each recipe was calculated to reach approximately $100 \mathrm{kcal}$.

Sample preparation was done in several stages. Samples Z1 and $\mathrm{Z} 2$ were obtained by primary processing that was carried out industrially by the supplier of plant-based puree juices and juices - Natural food manufacturer Ltd "KEEFA". Samples Z3 to Z5 were prepared in the Latvia University of Life Sciences and Technologies (LULST). The overall scheme of the experiment and processing modes is shown in Figure 1.

Product primary processing included cooking under vacuum or cook-vide. For recipes $\mathrm{Z} 1$ and $\mathrm{Z} 2$, vacuum cooking was done industrially using a vacuum cooking kettle (EV-150, Tecmon Srl., Italy). These samples were then were homogenised (MAGO, Bertoli Srl. con Socio Unico, Italy). Ascorbic acid was added and mixed into the product before packaging, to increase concentration of vitamin $\mathrm{C}$ in the finished product, taking into consideration the rapid reduction of vitamin $\mathrm{C}$ when using high processing temperatures. The low content of vitamin $\mathrm{C}$ in this type of product was noted in previous experiments on effect of vacuum cooking and

Table 1. Experimental sample plant-based ingredient input in each recipe

\begin{tabular}{l|c|c|c|c|c}
\hline \multirow{2}{*}{\multicolumn{1}{c}{ Ingredient }} & \multicolumn{5}{c}{$\begin{array}{c}\text { Sample plant-based ingredient } \\
\text { concentration per recipe (\%) }\end{array}$} \\
\cline { 2 - 6 } & Z1 & Z2 & Z3 & Z4 & Z5 \\
\hline Apple juice & - & 11.4 & 17.6 & - & 17.3 \\
Ascorbic acid & 0.1 & 0.1 & 0.1 & 0.1 & 0.1 \\
Red beetroot juice & 30.4 & 28.6 & 29.3 & 29.4 & 24.7 \\
Blackcurrant pulp juice & 5.9 & - & - & - & - \\
Cabbage juice & 15.4 & 14.3 & 17.6 & 17.6 & 14.8 \\
Carrot juice & - & - & 23.4 & - & 17.3 \\
Chokeberry pulp juice & - & - & 9.9 & - & - \\
Cod liver oil & 0.4 & 0.3 & 0.4 & 0.4 & 0.3 \\
Iodine salt & 0.04 & 0.04 & 0.04 & 0.04 & 0.03 \\
Jerusalem artichoke juice & 17.7 & 14.3 & - & 16.0 & - \\
Lingonberry pulp juice & - & - & - & 7.1 & - \\
Pumpkin juice & 28.3 & 23.5 & - & 24.1 & 14.8 \\
Rapeseed oil & 0.7 & 0.7 & 0.7 & 0.7 & 0.6 \\
Sea buckthorn pulp juice & - & 5.7 & - & 3.5 & - \\
Strawberry pulp juice & - & - & - & - & 9.4 \\
Whey protein isolate & 1.1 & 1.0 & 1.1 & 1.1 & 0.9 \\
Calculated energy value & 100.1 & 100.1 & 100.0 & 100.1 & 100.1 \\
per volume, kcal & & & & &
\end{tabular}




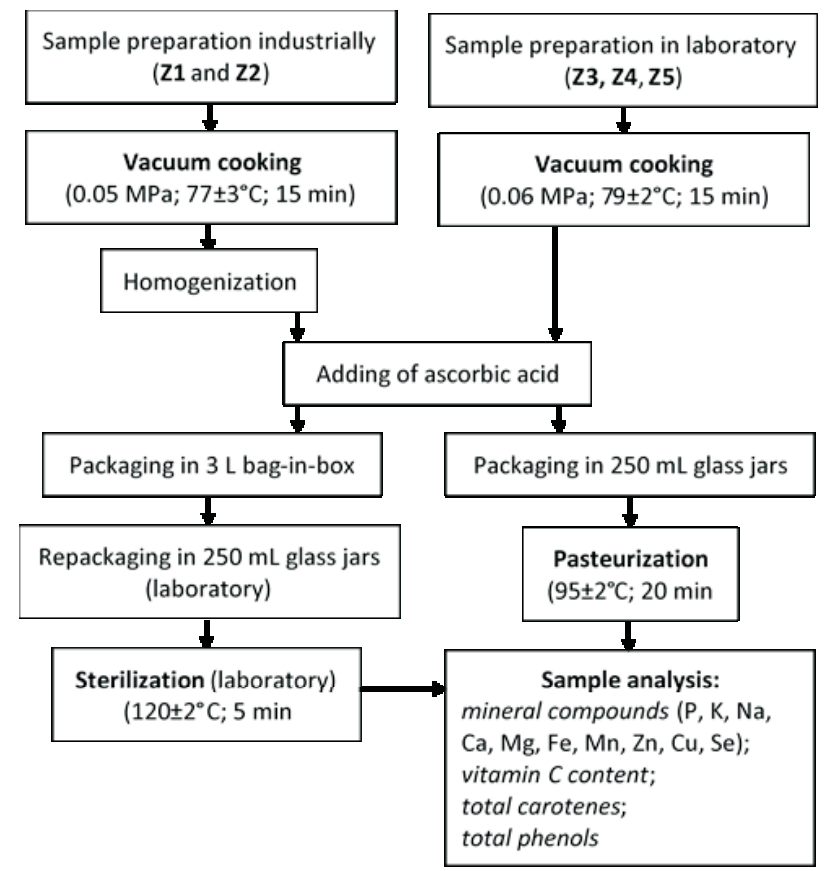

Fig. 1. General structure of the experiment.

high-pressure processing on enteral food made from fresh and semi-finished ingredients (Ozola et al., 2017; Ozola and Kampuse, 2017). Packaging was performed using a bag-inbox filler (MBF500, Voran Maschinen GmH, Austria). As secondary processing, the samples were sterilised. However, due to manufacturing circumstances, sterilisation was carried out in the LULST. Before sterilisation, the samples were repackaged in glass jars and the process was carried out using a ZIRBUS technology autoclave (HST 50/100, ZIRBUS technology GmbH, Germany).

Recipes Z3, Z4, and Z5 were prepared using laboratory pilot equipment. These samples were vacuum cooked using a STEPHAN UMC 5 (Stephan Machinery GmbH, Germany). Similarly, ascorbic acid was added to samples Z1 and Z2 and thoroughly mixed in all of the other samples, which were then packaged in glass jars. However, this time the samples were pasteurised as secondary processing treatment. Pasteurisation was done in a hot water bath (Fig.1).

All samples were cooled in a cold-water bath and stored refrigerated until testing. Concentrations of minerals $(\mathrm{P}, \mathrm{K}$, $\mathrm{Na}, \mathrm{Ca}, \mathrm{Mg}, \mathrm{Fe}, \mathrm{Mn}, \mathrm{Zn}, \mathrm{Cu}$, and $\mathrm{Se}$ ) and vitamin $\mathrm{C}$, total carotenes, and total phenol were determined.

Sample testing. The mineral (P, K, Na, Ca, Mg, Fe, Mn, $\mathrm{Zn}, \mathrm{Cu}$ ) concentrations were determined at the Institute of Biology, University of Latvia. Concentrations of $\mathrm{Ca}, \mathrm{Mg}$, $\mathrm{Fe}, \mathrm{Mn}, \mathrm{Zn}$, and $\mathrm{Cu}$ were determined using atomic absorption spectroscopy, and of $\mathrm{K}$ and $\mathrm{Na}$ with a flame photometer Jenway PFP7 (Cole-Parmer, UK). Concentration of P was determined colorimetrically with ammonium molybdate.

Concentration of Se was determined at the Institute of Food Safety, Animal Health and Environment "BIOR", using the standard BIOR-T-012-148-2013 method.
The concentration of vitamin $\mathrm{C}$ (ascorbic acid) was determined in LULST using the iodine titration method described by Kerch et al. (2011). This method is based on determination of L-ascorbic acid, the reduced form of ascorbic acid (Ozola and Kampuse, 2017). Concentration of vitamin $\mathrm{C}$ was calculated in two replications from two separate subsamples, and the results were expressed as $\mathrm{mg} \cdot 100 \mathrm{~g}^{-1}$ and $\mathrm{mg} \cdot 100 \mathrm{kcal}^{-1}$ of product.

Total carotene concentration was determined by spectrophotometry using a UV/VIS spectrophotometer Jenway 6705 (Bibby Scientific Ltd., UK), at $440 \mathrm{~nm}$ wavelength, as described previously (Poludek-Fabini and Beirih, 1981; Ermakova, 1987, pp. 112-113; Ozola et al., 2017). The concentration of carotene was calculated in two replications from two separate subsamples, and the results were expressed as $\mathrm{mg} \cdot 100 \mathrm{~g}^{-1}$ and $\mathrm{mg} \cdot 100 \mathrm{kcal}^{-1}$ of product.

Total phenol concentration was determined using the Folin-Ciocalteu method (Yu et al., 2003) with modifications:

- to $0.5 \mathrm{ml}$ of extracted sample, $2.5 \mathrm{ml}$ of $0.2 \mathrm{~N}$ FolinCiocalteu reagent diluted ten times with distilled water was added;

- after five minutes, $2.0 \mathrm{ml}$ of $7.5 \% \mathrm{NaCO}_{3}$ was added;

- the resulting solution was mixed and allowed to stand for 30 minutes at $18 \pm 1 \mathrm{riC}$ in the dark;

- absorption was read at $760 \mathrm{~nm}$ using a JENWAY 6300 (Banoworld Scientific Ltf., UK) spectrophotometer (Priecina and Karklina, 2014; Ozola et al., 2017).

Measurements were calculated from two replications from two separate subsamples, and the results were expressed as $\mathrm{mg} \cdot 100 \mathrm{~g}^{-1}$ and $\mathrm{mg} \cdot 100 \mathrm{kcal}^{-1}$ of product.

Statistical analysis. The obtained data analysis was done using MS Office Excel 2016. The obtained data were presented as means with standard errors. Significant differences between samples in vitamin $\mathrm{C}$, total carotene and total phenol concentration content were determined using single factor ANOVA followed by t-tests. Differences among results were considered to be significant if $p<0.05$.

\section{RESULTS}

The analysis of minerals in prepared enteral tube feed products showed only traces of Se $\left(<0.20 \mathrm{mg} \cdot \mathrm{kg}^{-1}\right.$ of sample). Similar findings were found in a previous study on mineral concentration in plant-based protein-enriched purees (Ozola and Kampuse, 2019). The levels of Se found in samples were not high enough for more precise determination, according to analytical results provided by BIOR. The EU regulation 2016/128 recommended quantity of Se in special dietary foods is between 2.5 to $10 \mu \mathrm{g} \cdot 100 \mathrm{kcal}^{-1}$ of product.

The concentration of zinc $(\mathrm{Zn})$ did not reach the minimum levels according to (EU) regulation 2016/128 (see Table 2). No samples exceed $0.3 \mathrm{mg} \cdot 100 \mathrm{kcal}^{-1}$. 
Table 2. Mineral compound concentration in analysed enteral tube feed products made from plant-based ingredients

\begin{tabular}{|c|c|c|c|c|c|c|c|}
\hline \multirow[t]{2}{*}{ Element } & \multicolumn{5}{|c|}{ Concentration in analysed samples (mg.100 $\mathrm{kcal}^{-1}$ of sample) } & \multicolumn{2}{|c|}{$\begin{array}{l}\text { Recommended mineral compound } \\
\text { concentration }\left(\mathrm{mg} \cdot 100 \mathrm{kcal}^{-1}\right)\left({ }^{1}\right)\end{array}$} \\
\hline & $\mathrm{Z} 1$ & $\mathrm{Z} 2$ & $\mathrm{Z3}$ & $\mathrm{Z4}$ & $\mathrm{Z5}$ & minimum & maximum \\
\hline $\mathrm{Ca}$ & $34.5 \downarrow$ & $27.8 \downarrow$ & 38.7 & 35.9 & $32.3 \downarrow$ & $35 / 50\left(^{2}\right)$ & $175 / 250\left(^{2}\right)$ \\
\hline $\mathrm{Cu}$ & 0.1 & 0.1 & 0.1 & 0.2 & 0.1 & 0.06 & 0.5 \\
\hline $\mathrm{Fe}$ & 0.8 & 0.8 & 0.6 & 0.7 & 0.8 & 0.5 & 2 \\
\hline K & $404.1 \uparrow$ & $345.2 \uparrow$ & $385.1 \uparrow$ & $397.0 \uparrow$ & $420.0 \uparrow$ & 80 & 295 \\
\hline $\mathrm{Mg}$ & $36.9 \uparrow$ & $29.2 \uparrow$ & $39.2 \uparrow$ & $33.2 \uparrow$ & $36.2 \uparrow$ & 7.5 & 25 \\
\hline $\mathrm{Mn}$ & 0.3 & 0.3 & 0.2 & 0.5 & 0.2 & 0.05 & 0.5 \\
\hline $\mathrm{Na}$ & 40.2 & 34.7 & 65.6 & 57.7 & 64.7 & 30 & 175 \\
\hline $\mathrm{P}$ & 36.0 & 34.8 & 45.2 & 30.8 & 32.6 & 30 & 80 \\
\hline $\mathrm{Zn}$ & $0.3 \downarrow$ & $0.3 \downarrow$ & $0.3 \downarrow$ & $0.3 \downarrow$ & $0.3 \downarrow$ & 0.5 & 1.5 \\
\hline
\end{tabular}

The direction of arrow added at the end of element content shows exceeded content compared to maximum level (up) and not reached levels, compared to minimum level (down)

${ }^{1}$ Data according to Commission delegated regulation (EU) 2016/128 (European Commission, 2015)

${ }^{2}$ For products intended for children of 1 to 10 years of age

Concentration of calcium (Ca), similarly to $\mathrm{Zn}$, did not reach the recommended minimum level (35 mg.100 kcal ${ }^{-1}$ ) in samples Z1, Z2, and Z5. In sample Z3 and Z4 the Ca concentration was $38.7 \mathrm{mg}$ and $35.9 \mathrm{mg} \cdot 100 \mathrm{kcal}^{-1}$ of product, which was only slightly higher than the recommended minimum (Table 2).

The concentrations of $\mathrm{Cu}, \mathrm{Fe}$, and $\mathrm{Mn}$ were similar between recipes (Table 2). The levels of $\mathrm{Cu}$ and $\mathrm{Fe}$ did fall within the recommended values, and tended to be below the minimum values, and thus it can be suggested to increase them.

The obtained data showed too high concentration the minerals potassium $(\mathrm{K})$ and magnesium $(\mathrm{Mg})$. On average, the analysed enteral tube feed products contain $32 \%$ higher $\mathrm{K}$ and $39 \%$ higher $\mathrm{Mg}$ than recommended. The highest concentration of $\mathrm{K}$ was detected in samples $\mathrm{Z} 5$ and $\mathrm{Z} 1$ and exceeded $400 \mathrm{mg} \cdot 100 \mathrm{kcal}^{-1}$ of sample. Sample Z3 contained the highest concentration of sodium (Na) 65.6 $\mathrm{mg} \cdot 100 \mathrm{kcal}^{-1}$, phosphorous (P) $45.2 \mathrm{mg} \cdot 100 \mathrm{kcal}^{-1}, \mathrm{Ca}$ $38.7 \mathrm{mg} \cdot 100 \mathrm{~g}^{-1}$ as well as $\mathrm{Mg} 39.2 \mathrm{mg} \cdot 100 \mathrm{kcal}^{-1}$, and it had the lowest concentration of $\mathrm{Cu}, \mathrm{Fe}$, and $\mathrm{Mn}$ (Table 2).

Concentration of vitamin $\mathrm{C}$ in prepared enteral tube feed products ranged between $70.7 \pm 1.5 \mathrm{mg} \cdot 100 \mathrm{~g}^{-1}$ in sample $\mathrm{Z} 5$ to $76.5 \pm 1.1 \mathrm{mg} \cdot 100 \mathrm{~g}^{-1}$ in sample Z2 (Fig. 2). The raised concentrations of vitamin $\mathrm{C}$ were due to the added ascorbic acid $(0.1 \%)$ during sample preparation. The sample recipes were supplemented with ascorbic acid, because previous experiments showed a significant deficiency of vita$\min \mathrm{C}$.

Significant differences $(p<0.05)$ were also found depending on the applied type of secondary treatment. Higher concentration of vitamin $\mathrm{C}$ occurred in sterilised $\left(120{ }^{\circ} \mathrm{C}, 5\right.$ min) samples $(\mathrm{Z} 1$ and $\mathrm{Z} 2)$ then in pasteurised $\left(95 \pm 2{ }^{\circ} \mathrm{C}, 20\right.$ min) samples, when expressed per $100 \mathrm{~g}$ of product, but did not show the same trend when recalculated to concentration per $100 \mathrm{kcal}$ of product.

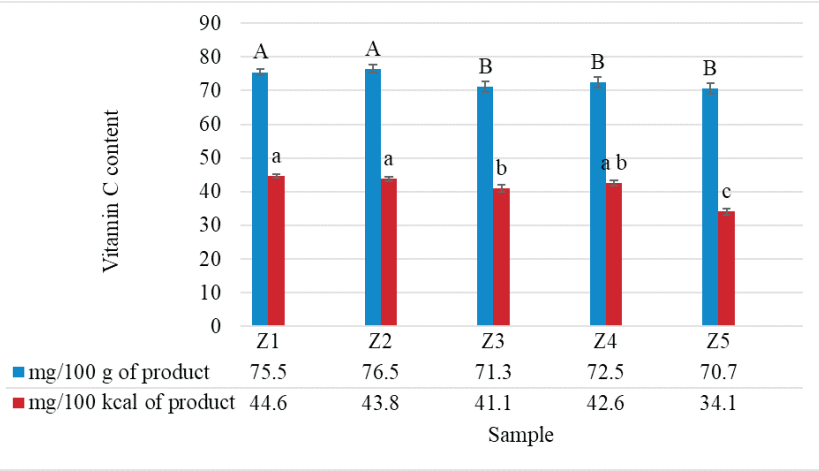

Fig. 2. Concentration of vitamin $\mathrm{C}$ in analysed enteral tube feed products made of plant-based ingredients. Means with the same letters on top of columns in a row were not significantly different $(p>0.05)$.

When compared to the recommended vitamin C levels $(2.25$ to $22 \mathrm{mg} \cdot 100 \mathrm{kcal}^{-1}$ of product) by (EU) regulation 2016/128, all samples exceeded the maximum level. Sample Z5 contained only $54.9 \%$ more, and samples Z1 and Z2 exceeded the recommended level by $102.6 \%$ and $98.9 \%$, respectively.

Significant differences $(p<0.05)$ were also found between the samples in their total carotene (Fig. 3) and total phenol concentration (Fig. 4). The highest total carotene and total phenol concentration was found in sample Z3, and the lowest levels were found in sample Z4, when compared per $100 \mathrm{~g}$ of product and $100 \mathrm{kcal}$ of product.

The total concentration of carotene in the samples ranged from $0.78 \pm 0.06 \mathrm{mg} \cdot 100 \mathrm{kcal}^{-1}$ to $1.64 \pm$ $0.10 \mathrm{mg} \cdot 100 \mathrm{kcal}^{-1}$, in samples Z4 and Z3, respectively. The total phenol concentration in ranged from $178.54 \pm$ $13.04 \mathrm{mg} 100 \mathrm{~g}^{-1}$ and $106.35 \pm 7.63 \mathrm{mg} \cdot 100 \mathrm{kcal}^{-1}$ product in sample Z3 (Fig. 4) to $78.05 \pm 3.83 \mathrm{mg} \cdot 100 \mathrm{~g}^{-1}$ and 45.24 $\pm 2.25 \mathrm{mg} \cdot 100 \mathrm{kcal}^{-1}$ in sample Z4. 


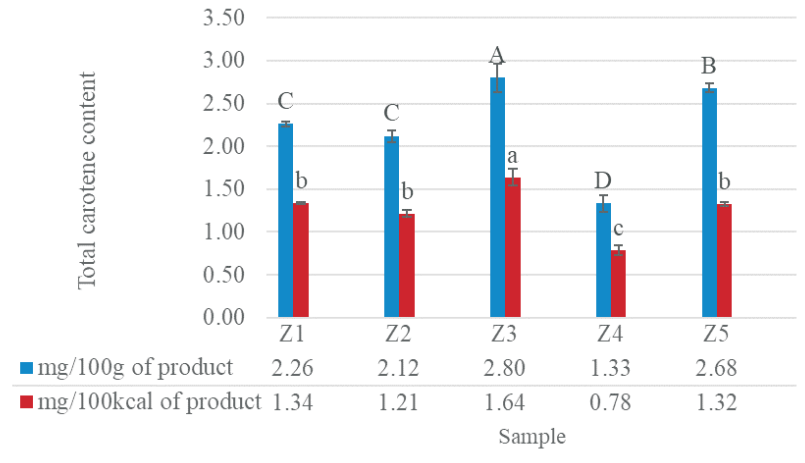

Fig. 3. Concentration of total carotene in analysed enteral tube feed products made of plant-based ingredients. Means with the same letters on top of columns in a row were not significantly different $(p>0.05)$.

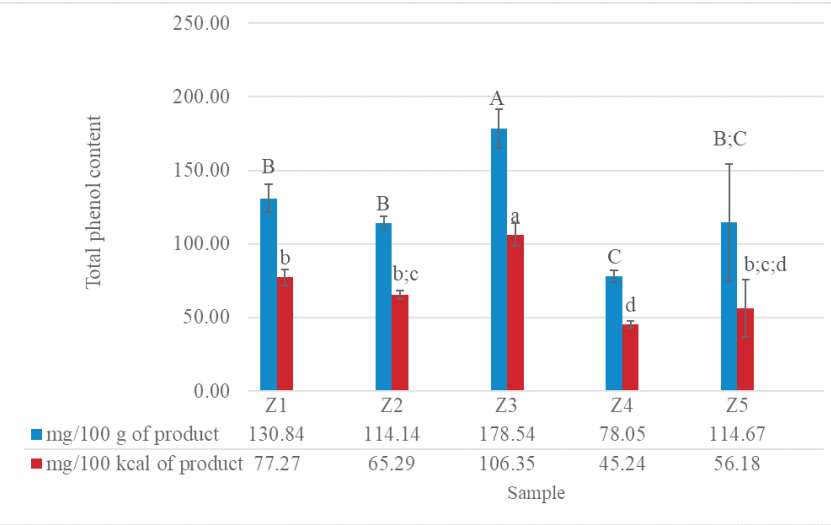

Fig. 4. Total phenol concentration in analysed enteral tube feed products made from plant-based ingredients. Means with the same letters on top of columns in a row were not significantly different $(p>0.05)$

\section{DISCUSSION}

Products for special medical purposes are a specific group of products that are a part of the recovery process for disabled persons. Intake of quality and nutritious foods plays an important role in human recovery, as it provides the body with everything it needs to function optimally.

The need for such products can have a variety of reasons, including neurological and neurodegenerative diseases, but also physical trauma, general aging, and others. In Europe, about $23 \%$ of elderly live independently, up to $51 \%$ are stationary patients and as many as $84 \%$ have some form of dementia or neurodegenerative disease involving dysphagia (Baijens et al., 2016).

Malnutrition can initially lead to a weakened immune system and increased susceptibility to infections as well as fatigue. Often, the symptoms associated with malnutrition are a direct result of nutrient deficiencies. In particularly severe cases, prolonged malnutrition can be fatal for both adults and children (Astley and Finglas, 2016).

Therefore, it is important to develop new products based on plant and animal raw materials, which could potentially be prepared under industrial conditions, thus reducing the risks and complications associated with the day-to-day preparation of such products.

The low levels of selenium in these products are very understandable. Selenium is found in the earth's crust, carbonate rock, volcanic and sedimentary soils (Santhosh Kumar and Priyadarsini, 2014). Although selenium is found in plants (leafy and green vegetables, nuts, whole grains) where it has been accumulated from soil, the levels of Se vary between location (Santhosh Kumar and Priyadarsini, 2014; Gharibzahedi and Jafari, 2017). Soils of Latvia do not contain significant amounts of selenium or its forms.

Dietary sources of $\mathrm{Zn}$ include both plants and animals. The highest concentration of $\mathrm{Zn}$ in the ingredients used in enteral tube recipes was in red beetroot and Jerusalem artichoke; both contained around $0.6 \mathrm{mg} \cdot 100 \mathrm{~g}^{-1}$, raw black currants contain $0.5 \mathrm{mg} \cdot 100 \mathrm{~g}^{-1}$ (DTU Fodevareinstituttet, 2019). Higher concentration of $\mathrm{Ca}$ is typically found in greens like broccoli, mustard greens, legumes, but mostly in animal products like milk and dairy products, canned salmon, and sardines with bones (Gharibzahedi and Jafari, 2017). The lack of these animal and plant products in the tested enteral tube feed products resulted in low amounts of $\mathrm{Ca}$ in the prepared samples.

For all of the enteral tube feed products, red beetroot (Beta vulgaris L.) juice was used as base not only because of its more neutral $\mathrm{pH}$, but also because of its nutritional composition. Red beetroot has been used as a home remedy since ancient times and its biological activity and nutritional composition as well as functional properties have been discussed much more in recent years (Vasiljeva et al., 2018). Red beetroot contains sufficient amounts of several minerals $(\mathrm{Na}, \mathrm{Mg}, \mathrm{K})$ vitamin $\mathrm{C}$, and bioactive compounds like betanin, carotenoids, and phenolic compounds, which are also strong antioxidants and can have antiviral, antioxidant, anti-inflammatory properties (Panghal et al., 2017; Vasiljeva et al., 2018; Chhikara et al., 2019; Ozola and Kampuse, 2019).

Other vegetable semi-finished juices like cabbage (Brassica oleracea var. capitate), carrot (Daucus carota L.), pumpkin (Cucurbitaceae), and Jerusalem artichoke (Helianthus tuberosus) were used to increase and diversify the concentration of minerals, and similarly fruit and berry semi-finished pulp juices were used to raise vitamin and bioactive compounds concentration.

Although there are no recommendations for concentration of total carotenes and total phenols, as bioactive compounds they have a positive impact on the human body. In contrast to nutrients, bioactive compounds are not essential, and therefore they have no recommended daily intake values. It is widely known that these compounds can reduce the risk of disease in individuals, some act as antioxidants, while others stimulate defence mechanisms that enhance the response to oxidative stress (Astley and Finglas, 2016). 


\section{CONCLUSIONS}

In conclusion, the obtained data showed that concentration of vitamin $\mathrm{C}$ in some samples exceeded the recommended $22 \mathrm{mg} \cdot 100 \mathrm{kcal}^{-1}$ maximum value by two times.

Regarding concentration of minerals, samples $\mathrm{Z} 1$ to $\mathrm{Z5}$ showed lack of selenium and low levels of $\mathrm{Ca}, \mathrm{Cu}, \mathrm{Fe}, \mathrm{Fe}$, and $\mathrm{Zn}$. However, $\mathrm{K}$ and $\mathrm{Mg}$ concentration was too high and exceeded the recommended maximum levels.

It is recommended to search for other ingredients that could provide higher concentration of the missing minerals or by adding mineral compound complexes to ensure the EU regulation 2016/128 recommended values.

There is a need to revaluate the amount of added ascorbic acid to reach the recommended levels of vitamin $\mathrm{C}$ throughout product storage.

Regarding the exceeded levels of minerals, the only solution is making corrections in product recipes. Otherwise these products cannot be considered as an only food source, but only as a part of supplementary diet.

\section{ACKNOWLEDGEMENTS}

The study was funded by the European Innovation Partnership for Agricultural Productivity and Sustainability Working Group Cooperation project No 18-00-A01612000006, "Development of Medicinal Food for Patients of Malnutrition/Dysphagia, Creating New, Nationally Significant Product With a High Added Value” (2018 to 2021).

\section{REFERENCES}

Astley, S., Finglas, P. (2016). Nutrition and Health. Wiley. https://onlinelibrary.wiley.com/doi/book/10.1002/9780470690611 (accessed 13 January 2022). DOI: 10.1002/9780470690611

Baijens, L. W. J., Clave, P., Cras, P., Ekberg, O., Forster, A., Kolb, G. F., Leners, J. C., Masiero, S., Mateos-Nozal, J., Ortega, O., Smithard, D. G., Speyer, R. (2016). European society for swallowing disorders - European union geriatric medicine society white paper: Oropharyngeal dysphagia as a geriatric syndrome. Clin. Intervent. Aging, 11, 1403-1428.

Campaniello, D., Corbo M. R., Sinigaglia M., Bevilacqua A. (2017). Thermal treatments for fruit and vegetable juices and beverages: A literature overview. Comprehensive Rev. Food Sci. Food Safety, 16 (4), 668-691.

Cederholm, T., Barazzoni, R., Austin, P., Ballmer, P., Biolo, G., Bischoff, S. C., Compher, C., Correia, I., Higashiguchi, T., Holst et al. (2017). ESPEN guidelines on definitions and terminology of clinical nutrition. Clin. Nutr., 36 (1), 49-64.

Chhikara, N., Kushwaha, K., Sharma, P., Gat, Y., Panghal, A. (2019). Bioactive compounds of beetroot and utilization in food processing industry: A critical review. Food Chem., 272, 192-200.

Druml, C., Ballmer, P. E., Druml, W., Oehmichen, F., Shenkin, A., Singer, P., Soeters, P., Weimann, A., Bischoff, S. C. (2016). ESPEN guideline on ethical aspects of artificial nutrition and hydration. Clin. Nutr., 35 (3), $545-556$.
DTU Fodevareinstituttet. (2019). Frida fooddata.dk.

https://frida.fooddata.dk/?lang=en (accessed 13.01. 2022)

Ermakova, A. I. (1987). Biochemical Research Methods of Plants [Ермакова, А. И. Методы биохимического исследования растений]. Agropromizdat, Moscow. 430 pp. (in Russian).

European Commission. (2016). Commission delegated regulation (EU) 2016/128 of 25 September 2015 supplementing Regulation (EU) No. $609 / 2013$ of the European Parliament and of the Council as regards the specific compositional and information requirements for food for special medical purposes. Off. J. Eur. Union, 2015 (March 1999), 30-43.

Ikase, L. (Ed.) (2015). Augḷkopība [Fruit-growing]. LV Augḷkopības institūts, Dobele. 567 lpp. (in Latvian).

Gharibzahedi, S. M. T., Jafari, S. M. (2017). The importance of minerals in human nutrition: Bioavailability, food fortification, processing effects and nanoencapsulation. Trends Food Sci. Technol., 62, 119-132.

Information on tube feeding, and formula options I Nestlé Health Science. https://www.nestlehealthscience.us/mytubefeeding/tubing-formulas (accessed 13.01.2022)

Karlsons, A., Osvalde, A., Pormale, G. (2018). Research on the mineral composition of cultivated and wild blueberries and cranberries. Agron. Res., 16 (2), 454.

Kerch, G., Sabovics, M., Kruma, Z., Kampuse, S., Straumite, E. (2011). Effect of chitosan and chitooligosaccharide on vitamin $\mathrm{C}$ and polyphenols contents in cherries and strawberries during refrigerated storage. Eur. Food Res. Technol., 233 (2), 351-358.

Lukaski, H. C. (2004). Vitamin and mineral status: Effects on physical performance. Nutrition, 20 (7-8), 632-644.

Ozola, L., Kampuse, S. (2019). Mineral and bioactive compound content in plant-based protein-enriched purees. Proceedings of $13^{\text {th }}$ Baltic Conference on Food Science and Technology "Food. Nutrition. Well-Being" and NEEFOOD $20195^{\text {th }}$ North and East European Congress on Food. LULST, Jelgava, pp. 149-153. DOI: 10.22616/FoodBalt.2019.020

Ozola, L., Kampuse, S. (2017). The effect of vacuum cooking on enteral food made from fresh and semi-finished ingredients. Res. Rural Dev., 1, 208-214.

Ozola, L., Kampuse, S., Galoburda, R. (2017). The effect of high-pressure processing on enteral food made from fresh or semi-finished ingredients. FoodBalt 2017: $11^{\text {th }}$ Baltic Conference on Food Science and Technology "Food Science and Technology in a Changing World". LULST, Jelgava, pp. 80-85. DOI:1022616/foodbalt.2017.008

Panghal, A., Virkar, K., Kumar, V. (2017). Development of probiotic beetroot drink. Curr. Res. Nutr. Food Sci., 5 (3), 257-262.

Poludek-Fabini, R., Beirih, T. (1981). Organic Analysis [Полюдек-Фабини, P., Бейрих, Т. Органический анализ]. Khimiya, Leningrad. 624 pp. (in Russian).

Priecina, L., Karklina, D. (2014). Natural antioxidant changes in fresh and dried spices and vegetables. Int. J. Biol. Biomol. Agric. Food Biotechnol. Eng., 8 (5), 492-496.

Santhosh Kumar, B., Priyadarsini, K. I. (2014). Selenium nutrition: How important is it? Biomed. Prev. Nutr., 4, 333-341.

Vasiljeva, S., Smirnova, G., Basova, N., Babarykin, D. (2018). Cadmium-induced oxidative damage and protective action of fractioned red beet (Beta vulgaris) root juice in chickens. Agron. Res., 16 (S2), 1517-1526.

Vieira, M. M. C., Santos, V. F. N., Bottoni, A., Morais, T. B. (2018). Nutritional and microbiological quality of commercial and homemade blenderized whole food enteral diets for home-based enteral nutritional therapy in adults. Clin. Nutr., 37 (1), 177-181.

Weimann, A., Braga, M., Harsanyi, L., Laviano, A., Ljungqvist, O., Soeters, P., Jauch, K. W., Kemen, M., Hiesmayr, J. M., Horbach, T., Kuse, E. R., 
Vestweber, K. H. (2006). Guidelines on enteral nutrition: Surgery including organ transplantation. Clin. Nutr., 25, 224-244.

Received 22 March 2021

Accepted in the final form 13 January 2022
Yeh, A., Conners, E. M., Ramos-Jimenez, R. G., Robers, M. B., Cheek, R., Ozolek, J., Mollen, K. P., Morowitz, M. J. (2019). Plant-based enteral nutrition modifies the gut microbiota and improves outcomes in murine models of colitis. Cell. Mol. Gastroenterol. Hepatol., 7 (4), 872-874.

\section{BIOAKTĪVO SAVIENOJUMU UN MINERĀLVIELU SATURS AUGU VALSTS IZEJVIELU BĀZES ENTERĀLĀ UZTURA PRODUKTOS}

Mūsdienās pieejamos produktus, kas paredzēti enterālā uztura nodrošināšanai, papildina sintētiskās sastāvdaḷas. Šo produktu efektivitāte medicīnas nozarē nav noliedzama, tomēr pastāv bažas par sintētisko vitamīnu un minerālu savienojumu biopieejamību salīdzinājumā ar dabiski sastopamajiem savienojumiem. Šì pētījuma mērkis bija izveidot caur zondi lietojamus enterālos produktus no augu bāzes izejvielām un pārbaudīt to bioaktīvo savienojumu un minerālvielu savienojumu saturu, kā arī salīdzināt iegūtās vērtības ar normām, kas rekomendētas Eiropas normatīvajā aktā par īpašu medicīnisku pārtiku, kas nav paredzēta zīdaiṇu uztura vajadzību apmierināšanai. Šim pētījumam no augḷu, ogu un dārzeņu pusfabrikātiem tika izgatavotas piecas škidrās formulas, kurām pievienots sūkalu olbaltumvielu izolāts, rapšu eḷla, mencu aknu eḷı, jodēta sāls un askorbīnskābe. Paraugi tika termiski apstrādāti, un tika noteikts C vitamīna, kopējo karotīnu, kopējo fenolu un minerālu savienojumu saturs: P, K, Na, Ca, Mg, Fe, Mn, Zn, Cu un Se. Pārskatot datus, saistībā ar (ES) 2016/128 prasībām visi paraugi uzrādīja nepietiekamu Se saturu $\left(<20 \mathrm{mg} \cdot \mathrm{kg}^{-1}\right)$ un arī nepietiekamu Zn saturu. Tomēr paraugos esošais $\mathrm{Mg}\left(345,2\right.$ līdz $420 \mathrm{mg} \cdot 100 \mathrm{kcal}{ }^{-1}$ produkta) un K (29,2 līdz 39,2 mg.100 kcall produkta) saturs pārsniedza maksimālo līmeni. C vitamīna saturs paraugos vismaz divas reizes pārsniedza ieteicamās normas, kas skaidrojams ar pievienoto L-askorbīnskābi, jo iepriekšējos eksperimentos parādījās neapmierinošs C vitamīna daudzums. 